\title{
ANALYSIS ON INTENTION OF PURCHASING ORGANIC FOODS BY THE UNDERGRADUATE STUDENTS OF IPB USING THE THEORY OF PLANNED BEHAVIOR APPROACH
}

\author{
Heppy Setiawati ${ }^{*}{ }^{1}$, Hartoyo $^{*}$, and Megawati Simanjuntak ${ }^{* *}$ \\ *) School of Business, Bogor Agricultural University \\ Pajajaran Street, Bogor 16151 \\ ${ }^{* *}$ Department of Family and Consumer Sciences, Human Ecology Faculty, Bogor Agricultural University \\ Kamper Street, IPB Dramaga Campus, Bogor 16680
}

\begin{abstract}
This study aims to identify factors that can increase the intention of buying organic foods and its implications in the design of organic food marketing strategy. The main model adopts Theory of Planned Behavior. Six variables were used in this study, namely, health awareness, environmental awareness, attitudes toward organic foods, subjective norms, perceptions of behavior control and organic food purchase intentions. The data to test the research model were collected from 140 respondents and were analyzed using statistical structural equation modeling method. The results of the study indicate that health awareness, environmental awareness, attitudes on organic foods, subjective norms and behavior control perceptions significantly influence the intention of buying organic foods. Furthermore, health awareness and environmental awareness have no significant effects on organic food purchase intention. The results of this study then become the basis in designing strategies to build a positive attitude on organic foods, subjective norms, and perceptions of consumer behavior control of organic foods that is by promoting organic foods through online or on certain events, creating new innovations so that the foods look attractive, and broadening market reach for organic food products to be more easily available.
\end{abstract}

Keywords: purchase intention, organic food, SEM-LISREL, marketing strategic, Theory of Planned Behavior

\begin{abstract}
Abstrak: Penelitian ini bertujuan mengidentifikan faktor-faktor yang dapat meningkatkan niat beli pangan organik, serta implikasinya dalam perancangan strategi pemasaran pangan organik. Model utama mengadopsi Theory Of Planned Behavior. Enam variabel digunakan dalam penelitian ini, yaitu kesadaran kesehatan, kesadaran lingkungan, sikap atas pangan organik, norma subjektif, persepsi kontrol perilaku dan niat beli pangan organik. Data untuk menguji model penelitian dikumpulkan sebanyak 140 responden. Data dianalisis menggunakan metode statistik structural equation modelling. Hasil dari penelitian menunjukkan bahwa kesadaran kesehatan, kesadaran lingkungan, sikap atas pangan organik, norma subjektif dan persepsi kontrol perilaku berpengaruh signifikan terhadap niat beli pangan organik. Selanjutnya, kesadaran kesehatan dan kesadaran lingkungan tidak berpengaruh signifikan terhadap niat beli pangan organik. Hasil penelitian ini kemudian menjadi dasar dalam merancang strategi untuk membangun sikap positif atas pangan organik, norma subjektif serta persepsi kontrol perilaku konsumen terhadap pangan organik, yaitu dengan melakukan promosi pangan organik melalui online atau pada acara tertentu, membuat inovasi baru agar terlihat menarik, serta menambah jangkauan pasar lebih luas agar produk pangan organik lebih mudah didapat.
\end{abstract}

Kata kunci: niat beli, pangan organik, SEM-LISREL, strategi pemasaran, Theory of Planned Behavior

\footnotetext{
${ }^{1}$ Corresponding author:

Email: happy.setiawati@gmail.com
} 


\section{INTRODUCTION}

Currently, health is the most important aspect and sought after by the community because it starts many diseases that appear and attack. A number of diseases that arise, among others, are the result of people's consumption of unhealthy foods. Now most people are beginning to turn to a healthy lifestyle because they do not want to get diseases. Healthy lifestyle that is applied includes eating healthy foods and doing exercises. To maintain their health, people usually consume fruits and vegetables, but nowadays fruits and vegetables also contain a large number of substances/ chemicals derived from the remaining pesticides and chemical fertilizers used during the production process which are not good for health and may also pollute the environment (Melisa, 2014).

Indonesian National Standard or SNI on organic foods (2002) states that organic is a labeling term stating that a product has been produced in accordance with the organic food system standards and certified by an Organic Certification Agency (LSO) accredited by the National Accreditation Committee (KAN). All organic food production processes are carried out naturally and should meet the established international requirement guidelines.

Organic food market in the world has a tendency to increase. Although organic food farming is not a big business, it shows a significant increase in its market (Hasrini and Setiaboedhi, 2017). In 1997, the new organic food market was worth approximately USD10 billion, but in 2013, the market reached approximately USD 72 billion (IFOAM, 2015). Meanwhile, world demand for organic agricultural products has grown by approximately $20 \%$ per year (Idaman et al. 2012). In Indonesia itself, organic farming programs are supported by the government, one of which is by arranging the standard organic farming system (Muzayanah et al. 2015). Nevertheless, the market share of organic food in Indonesia only grows about 5\% per year, with a sales value of about Rp10 billion (Handriana, 2014).

This is because organic food products have their own characteristics which becomes a challenge in marketing the products. The main factor that greatly weakens the position of organic foods compared with non-organic foods is the price (Hasrini and Setiaboedhi, 2017). Organic foods generally charge higher prices than nonorganic competitors because of higher raw material costs and/or more complicated processes. The combination of higher prices and intangible benefits puts organic food products to a lower position than non-organic products in the consumer's decision making process (Sari and Firmanzah, 2011).

Based on the theory of Planned Behavior (TPB), the actual behavior of a person in performing a particular action is directly influenced by his behavior intention, which is jointly determined by attitude, subjective norm and perception of behavioral behavior (perceived behavioral control) of the behavior. Behavioral intention is a measure of one's willingness to exert efforts when performing certain behaviors (Lee, 2008). Meanwhile, Ajzen (1991) defines intention as a motivational factor that influences behavior that is indicated by how hard people will try or how much effort is spent to perform a behavior. Attitude is a person's assessment on behavior that is profitable or not profitable. The subjective norms are defined as a social pressure that a person perceives in a behavior (Lee, 2008).

The last model of TPB has been empirically tested through validation, palication and replication process by many researchers according to Weng et al. (2014) and has also been tested by Lee and Yun (2015), Irianto (2015) and Kim and Chung (2013).

Else and Sihombing (2016) in their analytical studies integrate subjective norms on attitudes to buy and combine several other variables such as awareness of the environment, consumer perceptions, and health awareness. The study shows that consumer perceptions and attitudes to buy have a positive relationship to purchase intentions.

Sari and Firmanzah (2016) adopted the TPB model in this research and added the perceptions of risk and usefulness to credit card usage intentions, as independent variables that influence the dependent variable of intent on usage. Furthermore, Carolyn et al. (2013) in their study found that the moderate perceieved behavioral control had no influence on buying interest in organic self-care products. Indrasari (2016) in her research shows that there is a difference between respondents who choose inorganic and organic vegetables.

The variables used in this study included health awareness variables, environmental awareness, attitudes on organic foods, subjective norms, perceptions of behavior control and purchase intentions. Thus, the 
research model used here is different from that of the previous studies i.e. by using the basic model of TPB because it utilized the IPB student respondents who have a single tuition (UKT) of at least seven million rupiahs. Previous research used as the basis of this research model was conducted by Else and Sihombing (2016) with an attitude variable to buy, subjective norms and combination of several variables such as awareness of environment, consumer perception, and health awareness which influence the intention to buy organic foods in Y generation. Irianto (2015) uses health awareness, environmental awareness, organic food prices, buying attitudes, subjective norms, and differences in attitudes in the intention of purchasing organic food products between female and male consumers. Furthermore, Indrasari (2016) uses consumer perception variable toward inorganic and organic vegetables, marketing mix influence, consumer's attitude and buying interest toward buying decision of inorganic and organic vegetables in Bogor City. In this study, the writers used buying intentions influenced by health awareness, environmental awareness, attitudes toward organic food, subjective norms and behavioral control perceptions. Organic food attitudes are influenced by health awareness and environmental awareness as research variables. Therefore, this study aims to explore the factors that can increase the intention of the IPB S1 students from upper middle class in purchasing organic foods, as well as the implications in the design of marketing strategies, especially organic food products.

\section{METHODS}

The output of this study is the factors that need to be considered in the approach of using Theory of Planned Behavior for organic products that can increase purchasing intentions from consumers. For this reason, a research consisting of two stages in which in the first stage, identification of factors that influence the intention to buy organic foods was conducted. At this stage, research was conducted using the quantitative research method, which is a method of research to test certain theories through testing the relationship between variables using the research instruments (Creswell, 2016). The objects of the research in this first stage were students who had a single tuition (UKT) of at least seven million rupiahs. The respondents were S1 undergraduate students. The primary data needed in this research were obtained through a survey method with the aid of measurement instrument in the form of questionnaire. The questionnaire consisted of two parts where the first part was intended to find out the profile of the respondents, and the second part contained questions related to the research model.

An online questionnaire was created in Google Docs with links. The link was distributed through the Email application which aims to simplify and accelerate the distribution of the questionnaire. Data collection through questionnaires was conducted at IPB campus, and the distribution of questionnaires was conducted from July to August 2017.

The variables used in this study included health awareness, environmental awareness, attitudes on organic food, subjective norms, perceptions of behavior control and purchase intentions. The dependent variables in this research included the buying attitude of organic foods and the intention to buy organic food. The measurement instrument of each variable used the semantic differential measurement scale $(1=$ Strongly Disagree, up to $5=$ Strongly Agree). Health awareness was measured by 5 indicators, environmental awareness was measured by 5 indicators, attitudes on organic food were measured by 4 indicators, subjective norms were measured by 4 indicators, perception of behavior control were measured by 5 indicators, and the intention to buy organic food was measured by 5 indicators. Details of the indicators of each variable can be seen in Table 1 .

The sampling method used was judgment sampling, and S1 IPB students with a single tuition (UKT) of at least seven million rupiahs were chosen. The minimum number of samples taken refers to Hair et al. (2010), that states that the number of samples taken at least five times the number of parameters analyzed, and it will be more satisfactory if the number of sample is multiplied by ten times. General rules apply to multivariate analysis techniques in general, not specific to specific multivariate techniques. This study used 28 parameters in the form of questions in the questionnaire; thus, the minimum number of samples taken was $28 \times$ $5=140$ samples by using the ratio of the number of samples with the parameter equal to $5: 1$. The data from the questionnaire were then processed using the quantitative analysis methods, namely, descriptive and inferential statistical analyses. 
Table 1 . The results of actual research reliability test

\begin{tabular}{|c|c|}
\hline Variable & Indicator \\
\hline $\begin{array}{l}\text { Health awareness (COW): concerns } \\
\text { about personal health and motivation } \\
\text { to maintain health and quality of life by } \\
\text { means of healthy behavior. }\end{array}$ & $\begin{array}{l}\text { - Always think about personal health (KK1) } \\
\text { - Be alert to health changes (KK2) } \\
\text { - Be aware of health condition throughout the day (KK3) } \\
\text { - Always check your health regularly (KK4) } \\
\text { - Always pay more attention to health (KK5) }\end{array}$ \\
\hline $\begin{array}{l}\text { Environmental awareness (KL): } \\
\text { environmental concerns resulting from } \\
\text { non-organic foods that will influence the } \\
\text { environment. }\end{array}$ & $\begin{array}{l}\text { - Participate in efforts to reduce environmental damage (KL1) } \\
\text { - Engagement in current environmental activities will help save the } \\
\text { environment for future generations (KL2) } \\
\text { - Environmental preservation means great (KL3) } \\
\text { - Environmental preservation must be improved in Indonesia (KL4) } \\
\text { - Being angry against the way that an industry pollutes the environment (KL5) }\end{array}$ \\
\hline $\begin{array}{l}\text { Organic food attitudes (SP): evaluation } \\
\text { of favorable or unfavorable assessments } \\
\text { of organic foods. }\end{array}$ & $\begin{array}{l}\text { - Organic foods are preferred because they contain a lot of nutrients (SP1) } \\
\text { - Buying organic foods is healthier (SP2) } \\
\text { - Organic foods are preferred because they are natural food products (SP3) } \\
\text { - Eating foods that are free from synthetic preservatives is important (SP4) }\end{array}$ \\
\hline $\begin{array}{l}\text { Subjective norm (NS): refers to the } \\
\text { perceived social pressure to engage in or } \\
\text { not to engage in organic food purchasing } \\
\text { behavior. }\end{array}$ & $\begin{array}{l}\text { - Friends' influence in buying organic foods (NS1) } \\
\text { - Family's influence in buying organic foods (NS2) } \\
\text { - Doctors recommend in buying organic foods (NS3) } \\
\text { - Lecturer suggested in buying organic foods (NS4) }\end{array}$ \\
\hline $\begin{array}{l}\text { Perception of behavior control (KP): } \\
\text { Perceptions in the ease or difficulty in } \\
\text { performing organic food purchasing } \\
\text { behavior. }\end{array}$ & $\begin{array}{l}\text { - Awareness of the risks arising from consuming non-organic foods (KP1) } \\
\text { - Having enough time to choose organic foods to be purchased (KP2) } \\
\text { - Buying organic food is entirely self-control (KP3) } \\
\text { - Having enough money makes it easier to buy organic foods (KP4) } \\
\text { - Having good knowledge on the health benefits of organic foods (KP5) }\end{array}$ \\
\hline $\begin{array}{l}\text { The intention of purchasing organic } \\
\text { foods (NP): an inner component that } \\
\text { reflects how strong the intention of } \\
\text { purchasing organic food. }\end{array}$ & $\begin{array}{l}\text { - Intention of buying organic foods when sufficient money is available (NP1) } \\
\text { - Having a consideration that the first product to buy is organic foods (NP2) } \\
\text { - Intention of buying organic foods if they are available at a subscription store } \\
\text { or at a store close to the residence area (NP3) } \\
\text { - Having a plan to buy organic food if you have enough information on the } \\
\text { products (NP4) } \\
\text { - Having a plan to allocate some expenditure to buy organic foods if one has a } \\
\text { steady income (NP5) }\end{array}$ \\
\hline
\end{tabular}

Descriptive statistical analysis was primarily used to process the respondents' profile data and answers for each measurement item. The statistical measures used included average, frequency, and standard deviation. Inferential statistics were used to test the research model ability to explain the phenomenon of purchasing organic food intention using Structural Equation Modeling (SEM) method with the LISREL 8.3 program. This method was chosen in order to see the influence of each variable simultaneously.

The research model (Figure 1) and the hypothesis of this study are as follows:

H1 : Health awareness has a significant influence on the buying attitude of organic foods.
H2 : Environmental awareness has a significant influence on the attitude towards organic foods.

H3 : Health awareness has a significant influence on organic food purchase intentions.

H4 : Environmental awareness has a significant influence on purchase intention of organic foods.

H5 : Organic top food attitude has a significant influence on organic food purchase intentions.

H6 : subjective norms have a significant influence on organic food purchase intentions.

H7 : Perception of behavior control significantly influences organic food purchase intentions. 


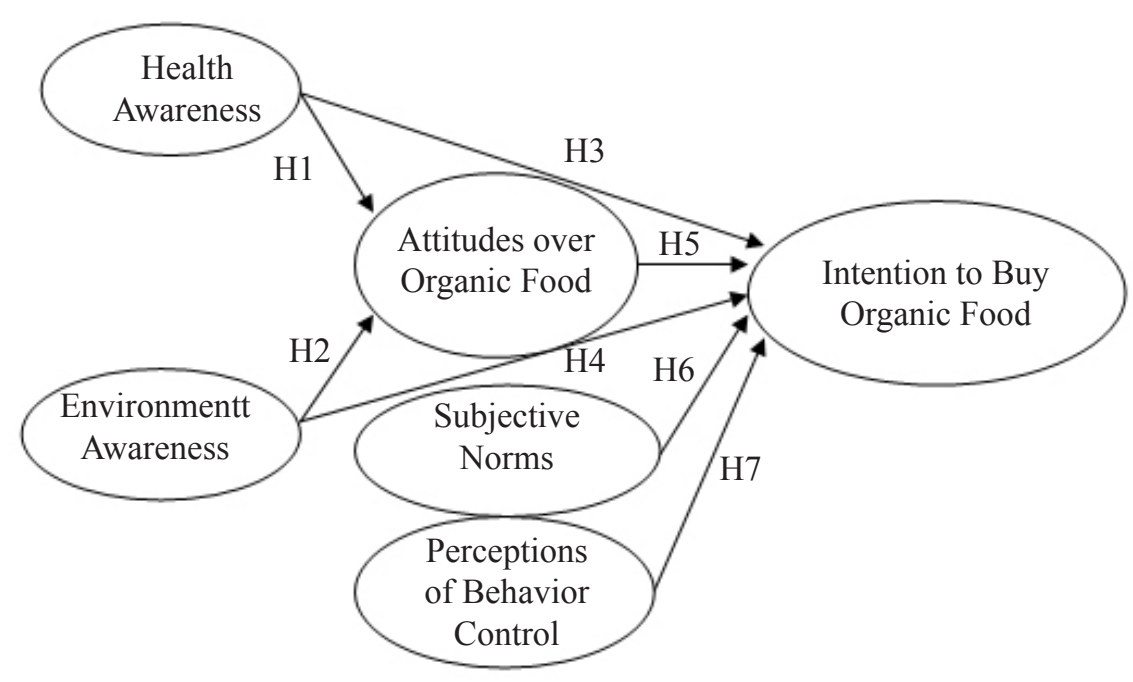

Figure 1. Research model

\section{RESULT}

The results of the processed data on the respondent profile showed that $70 \%$ of the respondents were females, and $58 \%$ of them had a single tuition fee (UKT) ranging from IDR7,000,001 to IDR9,000,001. Reliability testing in the actual research was conducted by looking at the values of Cronbach's alpha and corrected-item total correlation. The corrected-item value of the total correlations is greater than 0.30 (Tsiouris et al. 2003). Table 2 shows the results of the actual research reliability test. While the validity test of actual research was carried out by loading factor, AVE, and CR to test the validity of convergent, discriminant validity was tested using Pearson correlation. The loading factor values used in the EFA testing were adjusted to the number of research samples. There were 140 respondents taken as the samples of the research.

There are two stages of analysis in the SEM method, namely, the measurement model and the structural model (Hair et al. 2006). The measurement model test is done by Confirmatory Factor Analysis (CFA), an analytical tool to test how well the measured variable can describe the concept in small quantities (Hair et al. 2006). The CFA result is also seen from the SEM worthiness index value. The indeces used in this research included RMSEA, GFI, AGFI, and CFI. The followings are the results of these indices: $\mathrm{GFI}=0.93$; AGFI $=0.92$; RMSEA $=0.07$; CFI $=0.96$; therefore, it can be concluded that the model meets the minimum criteria for absolute match: RMSEA value is less than 0.8 , and GFI and CFI values are over 0.9 (Wijayanto, 2008). For the validity test, all absolute values of $t$ are greater than or equal to one and the standardized loading factor is more than 0.5. Wijayanto (2008) and Hair et al. (2010) state that the minimum acceptable factor loading factor is 0.5 . The result of reliability test shows that construct reliablity is $>0,7$ and variance extracted is $>0.5$. Because the conclusion of several dimensions resulted in the conclusion of goodness of fit model, hypothesis testing could be conducted.

The built model has values corresponding to the value limit required; thus, with the model used can describe information according to the data collected. Level of significance of relationship among the variables of both dimensions with latent variables and inter-latent variables used t-test with a significance level $\alpha$ of 0.05 $(\mathrm{t} \alpha / 2=1.96)$.

Figure 2 is an evaluation diagram that had been analyzed with SEM based on Tcount. It can be interpreted that all indicators of latent variables have significant influences in the form of health awareness, environmental awareness, subjective norms, behavior control perceptions, attitudes on organic foods, and intention of buying organic foods.

Standardized loading factor or the estimated value of the model load factor indicates the closeness of the dimensional variable with its latent variables. The amount of factor load value indicates the magnitude of the influence of each indicator in forming the latent variable. The greater the value of factor load, the greater the influence of the indicator in forming latent variables. 
Table 2. Actual research reliability test results

\begin{tabular}{|c|c|c|c|c|}
\hline Variable/Indicator & $\begin{array}{l}\text { Cronbach's alpha } \\
\text { Reliability }\end{array}$ & $\begin{array}{l}\text { Corrected-item total } \\
\text { correlation }\end{array}$ & $\begin{array}{l}\text { Construct } \\
\text { Reliability }\end{array}$ & AVE \\
\hline $\begin{array}{l}\text { Health Awareness } \\
\text { - KK1 } \\
\text { - KK2 } \\
\text { - KK3 } \\
\text { - KK4 } \\
\text { - KK5 }\end{array}$ & 0.807 & $\begin{array}{l}0.746 \\
0.768 \\
0.746 \\
0.664 \\
0.831\end{array}$ & 0.91 & 0.68 \\
\hline $\begin{array}{l}\text { Environment Awareness } \\
\text { - KL1 } \\
\text { - KL2 } \\
\text { - KL3 } \\
\text { - KL4 } \\
\text { - KL5 }\end{array}$ & 0.684 & $\begin{array}{l}0.556 \\
0.574 \\
0.583 \\
0.544 \\
0.530\end{array}$ & 0.83 & 0.51 \\
\hline $\begin{array}{l}\text { Attitudes over Organic Food } \\
\text { - SP1 } \\
\text { - SP2 } \\
\text { - SP3 } \\
\text { - SP4 }\end{array}$ & 0.784 & $\begin{array}{l}0.744 \\
0.786 \\
0.818 \\
0.701\end{array}$ & 0.85 & 0.59 \\
\hline $\begin{array}{l}\text { Subjective Norms } \\
\text { - NS1 } \\
\text { - NS2 } \\
\text { - NS3 } \\
\text { - NS4 }\end{array}$ & 0.809 & $\begin{array}{l}0.650 \\
0.697 \\
0.777 \\
0.703\end{array}$ & 0.92 & 0.70 \\
\hline $\begin{array}{l}\text { Perceptions of Behavior Control } \\
\text { - KP1 } \\
\text { - KP2 } \\
\text { - KP3 } \\
\text { - KP4 } \\
\text { - KP5 }\end{array}$ & 0.790 & $\begin{array}{l}0.685 \\
0.638 \\
0.659 \\
0.635 \\
0.720\end{array}$ & 0.91 & 0.72 \\
\hline $\begin{array}{l}\text { Purchase Value } \\
\text { - NP1 } \\
\text { - NP2 } \\
\text { - NP3 } \\
\text { - NP4 } \\
\text { - NP5 }\end{array}$ & 0.795 & $\begin{array}{l}0.669 \\
0.725 \\
0.698 \\
0.692 \\
0.661\end{array}$ & 0.86 & 0.55 \\
\hline
\end{tabular}

Hypothesis testing shows that of the seven hypotheses prepared, two hypotheses are not supported. Unsupported hypothesis included hypothesis 3 and hypothesis 4 while the hypotheses supported included hypothesis 1 , hypothesis 2 , hypothesis 5 , hypothesis 6 and hypothesis 7. Hypothesis 1 states that there is a positive relationship between health awareness with attitudes on organic foods. The results of hypothesis 1 were supported. Along with the development of the organic food market, questions arise on the reasons why someone purchases organic foods (Mc Carthy and Murphy, 2013). There are at least five motivations in the purchase of organic foods, namely, taste factor, food safety, health benefits, environmental factors, and ethics (McEachern and McClean, 2002). The thirdranked motivation is health benefits; therefore, it can be said that health awareness becomes one of the main motivations to encourage a positive attitude toward organic foods.

The results of Hypothesis 2 test state that there is a positive relationship between environmental awareness and attitude on organic foods. Hypothesis 2 is a supported hypothesis, and this can be due to the importance of cleanliness of the surrounding environment so that the beauty of the environment can be felt by the young generation of the future. 


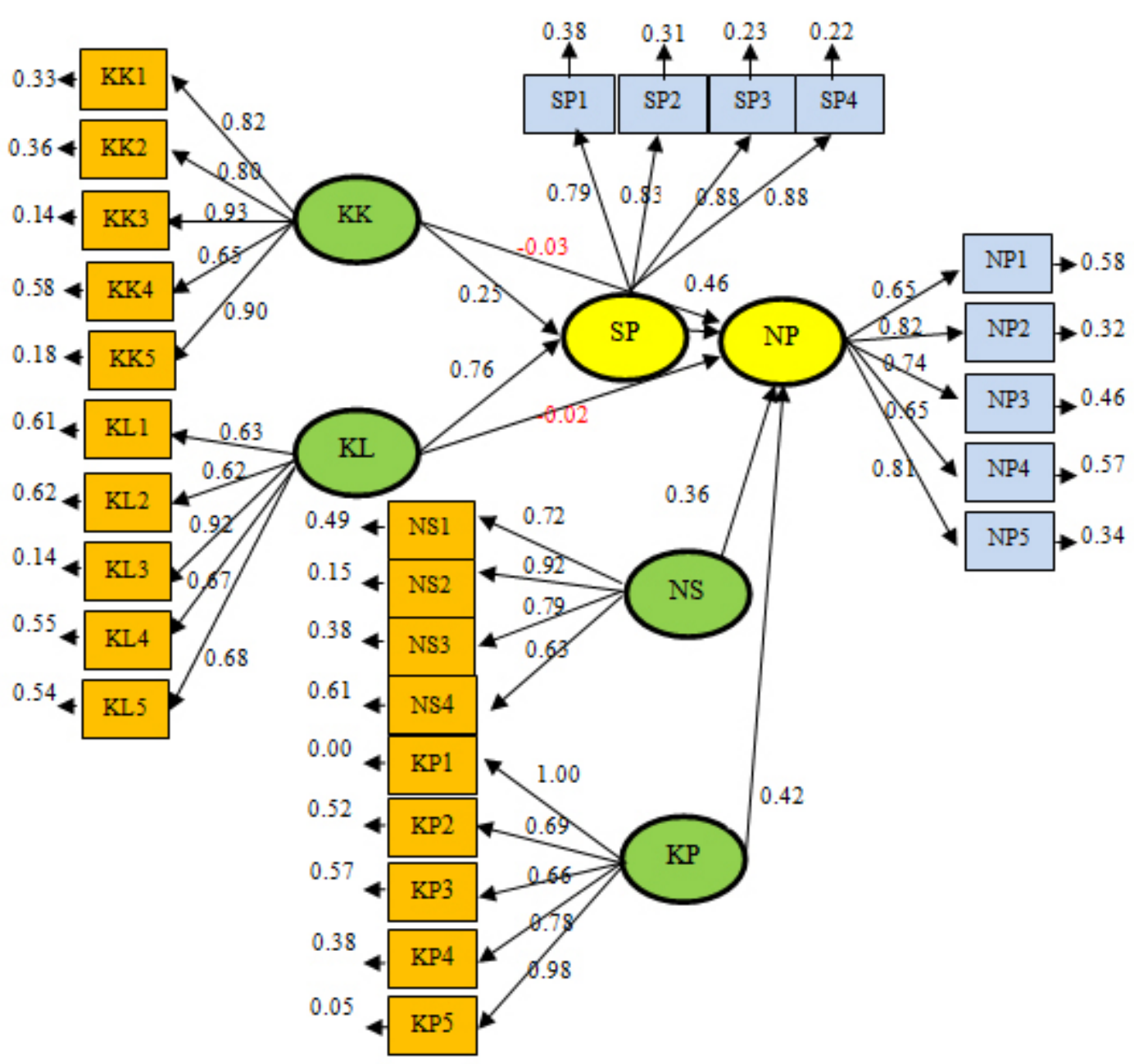

Figure 2. Evaluation of SEM Results

Hypothesis 3 states that there is a negative relationship between health awareness and purchase intentions, but the results of this hypothesis are not supported. The reason why this hypothesis is not supported is because someone who has a healthy lifestyle tends to choose healthy foods such as fruits and vegetables and does regular physical exercise or exercise (Divine and Lepisto, 2005). Health awareness depends not only on the type of food consumed alone, and physical activities such as sports are also considered to be a form of health awareness. Thus, the consumption of organic food is not the only factor that determines a person has health awareness or not (Eles and Sihombing, 2013). Previous research has also shown no positive relationships between health awareness and organic cosmetic buying intentions (Putri, 2016).

Hypothesis 4 states that there is a negative relationship between environmental awareness and purchase intentions; howver, the results of this hypothesis are not supported. This hypothesis is not supported because organic foods are focused only on their environmentally friendly products, so the consumers of organic foods are known to use environmentally friendly materials only but not for their healthful ingredients or good health effects.

Hypothesis 5 test result states that there is a positive relationship between attitude on organic food with purchase intentions. This hypothesis is a supported hypothesis. Intentions can be accurately predicted when attitudes toward intentions are high. Consumers tend to do a behavior if the person has a a positive attitude toward the behavior (Kim and Chung, 2011). This is caused by the attitude which is the basis of the formation of one's intentions. A positive attitude toward organic food will encourage consumers' intention in purchasing organic foods (Wijaya, 2014). The results of previous studies also found a positive relationship between buying attitudes and buying intentions (Jin and suh, 2005; Tarkiainen and Sundqvist, 2005; Chow and Chan, 2008; Michaelidou and Hassan, 2008; Han et al. 2010;Kim and Chung, 2011;Wijaya, 2014; Irianto, 2015). The next reason is the attitude to buy is an individual evaluation. Such evaluations may arise from personal experience. When a person has an 
experience in consuming organic food it will arise a positive evaluation of the product. Positive evaluation is what then encourages the intention of individuals to repurchase (Budiman and Wijaya, 2014).

The result of hypothesis test 6 states that there is a positive relationship between subjective norm and purchase intention. This hypothesis is a supported hypothesis. Hillhouse et al. (2000) in the context of behavior related skin management said that if the group of referents or individuals whose opinions are considered important by consumers like the food, the consumer's intention to buy the food will be greater. It can be concluded that the opinion of referent people or groups that are considered important and influential for consumers to like or agree to the consumption of organic foods will encourage their purchase intention.

Hypothesis 7 states that there is a positive relationship between the perception of behavioral control and purchase intentions. This hypothesis is a supported hypothesis. The emergence of consumer perceptions that organic foods are healthier than non-organic foods. Organic food itself is food free of pesticides and other chemicals (Carrington and Arnett, 2014), so the benefits of organic food for health become the consumers' motives to make purchases (Paul and Rana 2012). The results of previous studies also found a positive relationship between subjective norms and purchasing intentions (Kim and Chung, 2011; Eriyani and Wiyono, 2014).

\section{Managerial Implications}

There are four applied implications of this study that organic marketers need to pay attention in terms of consumer purchase intentions. Firstly, one positive attitude of consumers to organic food is influenced by health awareness and environmental awareness. Providing detailed information on organic foods can be carried out by marketers to maintain the products. Furthermore, it is also important for marketers to list the benefits of consuming them. Thus, consumers obtain an understanding on what benefits are obtained when consuming organic foods. A lack of understanding on the benefits of organic foods can be the cause of the low purchase intentions of the foods. Secondly, sometimes consumers prefer non-organic foods than organic foods that have higher prices than non-organic foods. One of the actions that a marketer can do is by promotion. Promotion can be done through posters, banners, or special promotions at certain time. The goal is to increase consumer sensitivity to organic food. Thirdly, the ease in purchasing organic foods also needs to be considered. Marketers must be able to reach a wider market so that consumers can obtain organic foods more easily. If the organic food is limited in a certain place, marketers must perform a wider distribution strategy. For example, making an intensive distribution of organic foods in large supermarkets such as Carrefour, Hypermart, Foodmart, and so forth. Fourthly, retail and marketers can work together to see the development of sales in a certain period.

\section{CONCLUSIONS AND RECOMMENDATIONS}

\section{Conclusions}

This study aims to identify the influences of health awareness, environmental awareness, and attitudes on organic foods, subjective norms, and perceptions of behavior control. The results show that health awareness and environmental awareness have a positive relationship to attitudes over organic foods. Then, the attitude of organic food has a positive influence on the purchase intention of organic food, subjective norm also positively influences the intention of purchasing organic food. In addition, perceptions of consumer behavior control also positively influence the intention of purchasing organic foods. Of the seven hypotheses prepared, there are two unsupported hypotheses i.e. the relationship of the awareness of the environment and health toward the purchase intention.

\section{Recommendations}

This research is also inseparable from limitations, and there are four limitations in this study. The first limitation is the objects of this study are organic foods which include vegetables, fruits and food using organic materials. Thus, these organic foods do not represent other organic products. Therefore, the results of this study can only be implemented on organic foods alone. The second limitation is that the samples in this study were students of S1 IPB with an average age of 1821 years old. The samples used in the study tend to be homogeneous. The third limitation is that the results of this study cannot be generalized at the population level but only applicable to study respondents only. The last limitation is that the researcher did not do the research until the purchasing behavior. 


\section{REFERENCES}

Ajzen I. 1991. Belief, Attitude, Intention and Behavior: An Introduction to Theory and Research. Reading, MA: Addison-Wesley.

Budiman S, Wijaya T. 2014. Purchase intention of counterfeit products: the role of subjective norm. International Journal of Marketing Studies 6(2):145-152.

Carrington D, Arnett G. 2014. Guardian News and Media Limited. United Kingdom: The Guardian.

Carolyn G, Pusparini ES, Elok Savitri. 2013. Analisis faktor- faktor yang mempengaruhi minat beli (Purchase Intention) konsumen terhadap produk perawatan diri berbahan organik [tesis]. Depok: Universitas Indonesia.

Chow WS, Chan LS. 2008. Social Network, Social Trust and Shared Goals in Organizational Knowledge Sharing. Information \& Management 45: 458465. https://doi.org/10.1016/j.im.2008.06.007.

Creswell J. 2016. Research Design Pendekatan Metode Kualitatif, Kuantitatif, dan Campuran Edisi 4. Yogyakarta: Pustaka Belajar.

Divine RL, Lepisto L. 2005. Analysis of the healthy lifestyle consumer. Journal of Consumer Marketing 22(5): 275-283. https://doi. org/10.1108/07363760510611707.

Else SF, Sihombing. 2016. Determinan niat beli makanan organik: sikap untuk membeli sebagai variabel mediasi. Jurnal Ilmiah Manajemen 6(3):313-332.

Eriyani, Wiyono. 2014. Pengaruh Sikap, Persepsi Kontrol Perilaku, dan Norma Subjektif pada Intensi Beli Kosmetik Organik: Studi pada Mahasiswa Universitas Sebelas Maret Surakarta. Fokus Manajerial 11(2): 140-154.

Handriana E. 2014. Pertumbuhan pangan organik nasional hanya 5 Persen. http://www. suaramerdeka.com. [23 Juli 2016].

Hair JF, Black WC, Babin BJ, Anderson RE. 2010. Multivariate Data Analysis: A Global Perspective 7th Ed. Upper Saddle River. New Jersey: Pearson Education, Inc.

Hasrini S, Setiaboedhi AP. 2017. Faktor-faktor yang mempengarhi minat beli pangan organik Melalui situs online. Jurnal Manajemen \& Agribisnis 14(1): 54-64.

Hillhouse J, Turrisi R dan Kastner M. 2000. Modeling tanning salon behavioral tendencies using appearance motivation, self-monitoring and the theory of planned behavior. Health Education Research 15(4): 405-414. https://doi. org/10.1093/her/15.4.405.

Idaman N, Yuliarti LN, Retnaningsih. 2012. Sikap konsumen terhadap beras organik. Jurnal Manajemen \& Agribisnis (9)2: 117-126.

IFOAM. 2015. Global organic market at 72 billion US dollars with 43 million hectares of organic agricultural land worldwide.

Indrasari V. 2016. Analisis perbandingan sikap dan minat konsumen dalam membeli sayuran anorganik dan organik di Kota Bogor [thesis]. Bogor: Institut Pertanian Bogor.

Irianto H. 2015. Consumers' attitude and intention towards organic food purchase: an extension of theory of planned behavior in gender perspective. International Journal of Management, Economics and Social Sciences 4(1):17-31.

Jin B, Suh YG. 2005. Integrating effect of consumer perception factors in predicting private brand purchase in a korean discount store context. Journal of Consumer Marketing 22(2): 62-71. https://doi.org/10.1108/07363760510589226.

Kim HY, Chung JE. 2011. Consumer purchase intention for organic personal care product. Journal of Consumer Marketing 28(1):40-47. https://doi. org/10.1108/07363761111101930.

Lee K. 2008. Opportunities for green marketing: Young consumers. Marketing Intelligence \& Planning 26(6): 573-586.

McCarthy B, Murphy L. 2013. Who's buying organic food and why? Political consumerism, demographic characteristics and motivations of consumers in North Queensland. Tourism \& Management Studies 9(1): 72-79. https://doi. org/10.1046/j.1470-6431.2002.00199.x.

McEachern M, McClean P. 2002. Organic purchasing motivations and attitudes: are they ethical? International Journal of Consumer Studie 26(2): $85-92$.

Melisa K. 2014. Produk pertanian organik Indonesia: tinjauan atas preferensi konsumen Indonesia terhadap produk pertanian organik lokal. Jurnal Studi Manajemen 8(2):171-173.

Michaelidou N, Hassan LM. 2008. The role of health consciousness, food safety concern and ethical identity on attitudes and intention towards organic food. International Journal of Consumer Studies 32(2):163-170. https://doi.org/10.1111/ j.1470-6431.2007.00619.x. 
Muzayanah FN, Suroso AI, Najib M. 2015. Faktorfaktor yang memengaruhi resistensi pembelian pangan organic dan proses pendidikan konsumen. Jurnal Manajemen \& Agribisnis 12(3):163-173. https://doi.org/10.17358/JMA.12.3.163.

Paul J, Rana J. 2012. Consumer behavior and purchase intention for organic food. Journal of Consumer Marketing. 29 (6): 412-422.

Putri DM. 2016. Intensi pembelian kosmetik organik pada mahasiswa bandar lampung [thesis]. Bandar Lampung: Universitas Lampung.

Sari H dan Firmanzah. 2011. Segmentation for environmental friendly products and its implication to product design: Indonesian context. Di dalam: Proceeding of 2011 IEEE International Summer Conference of Asia Pacific; Dalian, 1012 July 2011. Tiongkok: Business Innovation and Technology Management (APBITM), hlm. 168-171.

[SNI] Standar Nasional Indonesia. 2002. Sistem Pangan Organik SNI 01-6729-2002. Jakarta: SNI.
Tarkiainen A, Sundqvist S. 2005. Subjective norms, attitudes and intentions of finnish consumer in buying organic food. British Journal Food 107(11): 808-822.

Tsiouris J, Mann R, Patti P, dan Sturmey P. 2003. Challenging behaviours should not be considered as depressive equivalents in individuals with intellectual disability. Journal of Intellectual Disability Research 47: 14-21. https://doi. org/10.1046/j.1365-2788.2003.00456.x.

Weng ML, Shuang JL, Suryadi K. 2014. Consumer's perceived value and willingness to purchase organic food. Journal of Global Marketing 27(5): 298-307.

Wijayanto SH. 2008. Structural Equation Modelling (SEM) dengan LISREL 8.8: Konsep dan Tutorial. Yogyakarta: Graha Ilmu.

Wijaya T. 2014. Nilai dan Pengetahuan Sebagai Prediktor Intensi Beli Makanan Organik. Jurnal Manajemen dan Kewirausahaan 16(1):69-82. https://doi.org/10.9744/jmk.16.1.69-82. 